This item was submitted to Loughborough's Research Repository by the author.

Items in Figshare are protected by copyright, with all rights reserved, unless otherwise indicated.

\title{
Landfill stability and integrity: the UK design approach
}

PLEASE CITE THE PUBLISHED VERSION

http://dx.doi.org/10.1680/warm.2007.160.2.51

PUBLISHER

(C) ICE Publishing Ltd.

VERSION

VoR (Version of Record)

LICENCE

CC BY-NC-ND 4.0

REPOSITORY RECORD

Fowmes, Gary John, Neil Dixon, and D. Russell V. Jones. 2019. "Landfill Stability and Integrity: The UK Design Approach”. figshare. https://hdl.handle.net/2134/11460. 
This item was submitted to Loughborough's Institutional Repository (https://dspace.lboro.ac.uk/) by the author and is made available under the following Creative Commons Licence conditions.

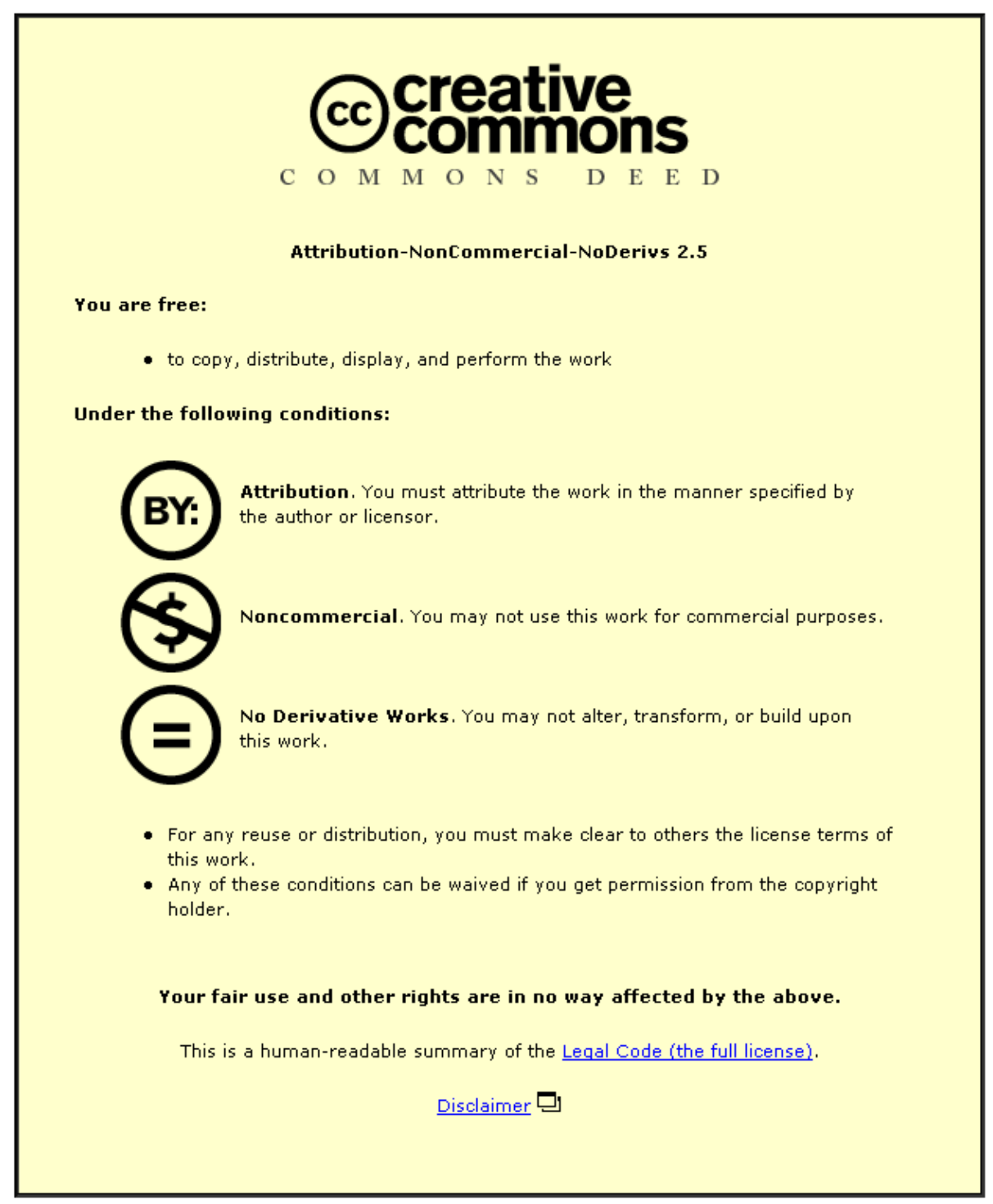

For the full text of this licence, please go to: http://creativecommons.org/licenses/by-nc-nd/2.5/ 

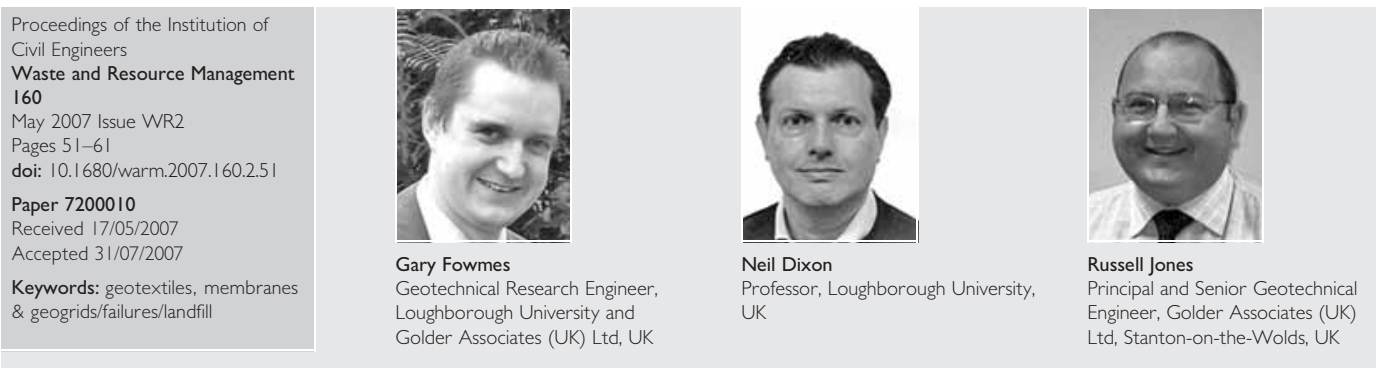

\section{Landfill stability and integrity: the UK design approach}

G. Fowmes BSc, MSc, FGS, N. Dixon PhD, FGS and D. R. V. Jones PhD, CEng, MICE, MCIWM, FCIArb, FGS

This paper highlights the design considerations, in terms of stability and integrity, for EC Landfill Directive compliant sites. The paper details a design chart based on research and development reports produced for the Environment Agency (England and Wales) intended to guide designers and highlight areas for consideration in each of six aspects of landfill construction: subgrade, basal lining system, shallow-slope lining system, steep-slope lining system, waste slopes and capping lining systems. The paper is not intended to offer design methodologies in terms of which calculation methods should be adopted, but to provide designers with a framework in which to apply engineering skill and judgement and to highlight challenges.

\section{INTRODUCTION}

A 2003 report on UK landfills identified over 85 failures. ${ }^{1}$ Although the majority of these failures were recorded during landfill construction and could thus be easily remediated, there were still significant cost implications. The failures were primarily attributed to inadequate site investigation, uncontrolled groundwater and inappropriate design. This highlights the need for guidance on the design of landfill lining systems.

A literature review (report TR1) ${ }^{2}$ and a guidance document (report TR2) ${ }^{3}$ for assessment of the stability and integrity of landfill lining systems have been produced for the Environment Agency.

Application of the guidance provides a framework for the assessment of six aspects of landfill stability and integrity: subgrade, basal lining systems, shallow-slope lining systems, steep-slope lining systems, waste slope stability and capping lining stability.

In England and Wales, operation of landfills requires a pollution prevention and control (PPC) permit. The stability risk assessment requirements for the permit application are based on guidance TR2. ${ }^{3}$ This paper presents the design considerations for each of the six aspects and discusses the key considerations. To date, over 600 copies of guidance TR2 ${ }^{3}$ have been distributed by the Environment Agency in response to orders from designers, operators and researchers both in the UK and overseas. This paper considers the key aspects of landfill design and provides an updated summary of current design approaches. Areas for future consideration are highlighted.

\section{I.I. Typical lining system}

A typical lining system comprises barrier, protection and drainage layers formed from geological (e.g. clay and gravel) and geosynthetic (e.g. geomembrane and geotextile) materials. Fig. 1 shows a typical lining system. A barrier layer is required to limit the leakage of fluids (both liquid and gas) from the waste mass into the surrounding environment. Examples of barrier layers include compacted clay, bentonite-enriched soil (BES), colliery spoil, polymeric geomembranes and geosynthetic clay liners (GCLs).

For non-hazardous landfills (e.g. those taking municipal solid waste), the 1999 EC Landfill Directive, ${ }^{4}$ enforced in the UK through the 2002 Landfill Regulations, ${ }^{5}$ requires a geological barrier to aid attenuation of contaminants. With properties equivalent to a thickness of $1 \mathrm{~m}$ and hydraulic conductivity of $1 \cdot 0 \times 10^{-9} \mathrm{~m} / \mathrm{s}$, the barrier is required along the base and up the sides of landfill sites. The thickness can be reduced to a minimum of $500 \mathrm{~mm}$ if the permeability of the barrier layer is decreased. In the UK, the geological barrier is typically formed from compacted clay or BES (artificially established geological barriers) and may also include low permeability in situ materials (natural geological barriers).

In order to further reduce leakage from a landfill, composite liners can be used where a combination of barrier materials provides a greatly reduced hydraulic conductivity. The most common composite lining system involves a compacted mineral liner overlain by a polymeric geomembrane, where the geomembrane is in close contact with the mineral liner; hence any fluids migrating through defects in the geomembrane must still pass through the mineral liner whilst the hydraulic head across the mineral liner is significantly reduced by the presence of the geomembrane.

It is important to protect the geomembrane from damage both during and following installation. A geotextile protection layer is typically placed above a geomembrane to protect the membrane from the overlying materials. The performance of a lining system is improved by control of the leachate head acting on it, and it is common practice to include a drainage layer above the lining system. The drainage layer can be a granular mineral layer or a polymeric drainage composite.

\section{DESIGN ISSUES}

\section{I. General}

Site investigation should provide designers with confidence in parameters selected for use in analyses. Inadequate site investigation may not only lead to inappropriate design parameters being selected but can also lead to critical failure 


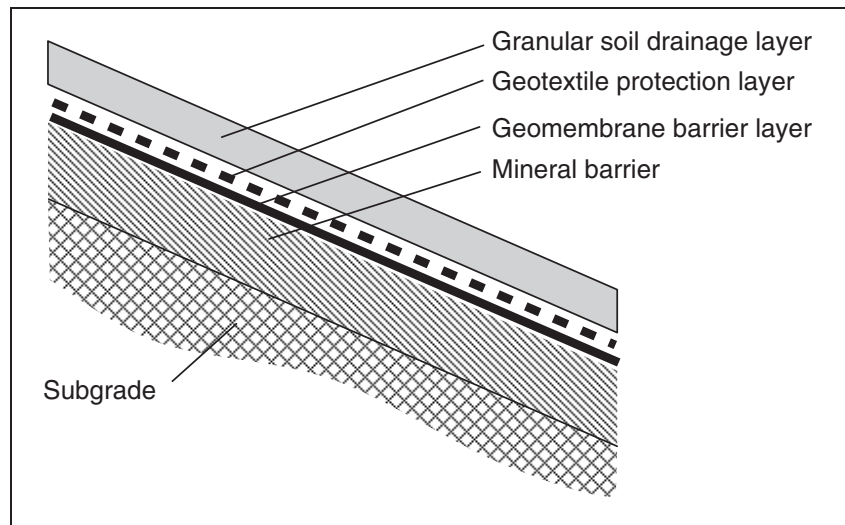

Fig. I. A typical landfill lining system

mechanisms being overlooked. For landfill design, knowledge of the subgrade, groundwater regime and material properties of in situ and engineered materials is required. In an ideal scenario the waste mechanical properties would be known. However, due to the waste heterogeneity, composition and particle size, this is difficult, although ranges of likely waste parameters must be obtained as discussed in section 3.4.2.

When analysing barrier layers, the allowable strains must be considered. In a mineral barrier this will depend on the soil plasticity. High-plasticity fine-grained soil may be subjected to greater deformations than low-plasticity soil before the permeability of the soil rises. For polymeric geosynthetic liners, polymer type, material thickness and design life will all affect the allowable strains. The designer must justify the selected materials and the design to show that the allowable deformations do not adversely affect barrier performance.

A very important design consideration is how the system will be constructed. Safe working must be ensured during construction as detailed in The Construction (Design and Management) Regulations (2007). ${ }^{6}$ It is the designer's responsibility to ensure that all potential hazards are eliminated or minimised. Working at heights and at the base of high slopes must be kept to a minimum; this is of particular importance in steep-sided landfill lining systems.

The design life of a geomembrane will depend on the polymer type, additive package applied to the polymer and the environmental conditions (including the temperature generated within the landfill and the leachate chemistry). It is widely accepted that the geomembrane will have a finite period of functionality and the design life of the system must be sufficient to allow the waste mass to become stable and all contaminated leachate to have been treated. In the long term, geosynthetic lining system components will degrade. ${ }^{7}$ A designer must firstly consider the impact of this on the containment function of a lining system. Hydrogeological and landfill gas risk assessments should take into account the loss of functionality of polymeric lining system components at a given number of years into the life of the system.

\subsection{Interface shear strength considerations}

The interfaces between lining system components, in particular where planar geosynthetic materials are present, may provide preferential slip planes. The strength of these interfaces can be highly variable, and large variability in shear strength can result from the testing laboratory used as well as material variations. ${ }^{8}$ Literature data should be used with caution as they may not be representative of on-site conditions. Site-specific testing should be conducted to verify or enable detailed design to be carried out. Such testing should involve performance rather than index testing with representative material above and below the interface. In addition to interface shear strength variability, the internal shear strength will also need to be considered if composite materials or GCLs are used. GCL internal shear strength variability is high when comparing different manufacturing lot specimens-the natural variability of bentonite material has been shown to play a part in this. ${ }^{9}$ It is important to include site-specific testing in order to reduce the uncertainty associated with interface shear strength variability.

Eurocode 7 defines the characteristic value of a soil property as 'a cautious estimate of the value affecting the occurrence of the limit state'. ${ }^{10}$ With mineral, polymeric and interface properties, an understanding of the associated variability of the parameter will allow the designer to select a cautious estimate. Further sitespecific testing will increase confidence in the selected parameters.

Leachate and gas pressures may be present at an interface and designers must consider whether fluid pressures could act there. Interfaces separated from the waste mass by a barrier layer are less likely to have elevated leachate and gas pressures acting on them than those not separated from the waste. In limit equilibrium analyses the use of peak or residual values in design can greatly influence the calculated factors of safety for a given design. ${ }^{11,12}$ The use of peak strength may be unconservative if sufficient displacement occurs to induce post peak shear strength reduction. ${ }^{13}$ A landfill failure where a compacted clay barrier layer failed along an interface with an underlying polymeric geocomposite drain has been reported. ${ }^{2}$ Back analysis of the failure showed that post peak interface conditions were required to generate a factor of safety of 1 . It is believed that repeated plant loading from heavy dump trucks using a diagonal haul road in the vicinity of the failure caused post peak shear strength to be mobilised. Numerical modelling techniques can be used to represent strain-dependent interface shear strength, although concerns still surround the accuracy of the input data associated with such analyses. ${ }^{14}$

\section{DESIGN CONSIDERATIONS}

Figure 2 shows the six main elements of a landfill containment system and Fig. 3 presents the individual design considerations for each of the design cases, including key controlling factors, which should be considered when assessing landfill stability and integrity. The fundamental aspect of a safe design is to select the potential critical failure mechanisms, either in terms of stability or integrity, then to assess these using relevant analytical methods using site-specific parameters. Although each aspect of design should be considered, this does not imply that a calculation must be done in every case. A logical argument can be put forward as to why a particular failure mechanism is not considered to be likely.

The lining system and subgrade should be considered prior to, during and after construction. Unconfined conditions occur in the subgrade prior to construction and in the lining system prior to waste placement. In side slope lining systems, particularly those 


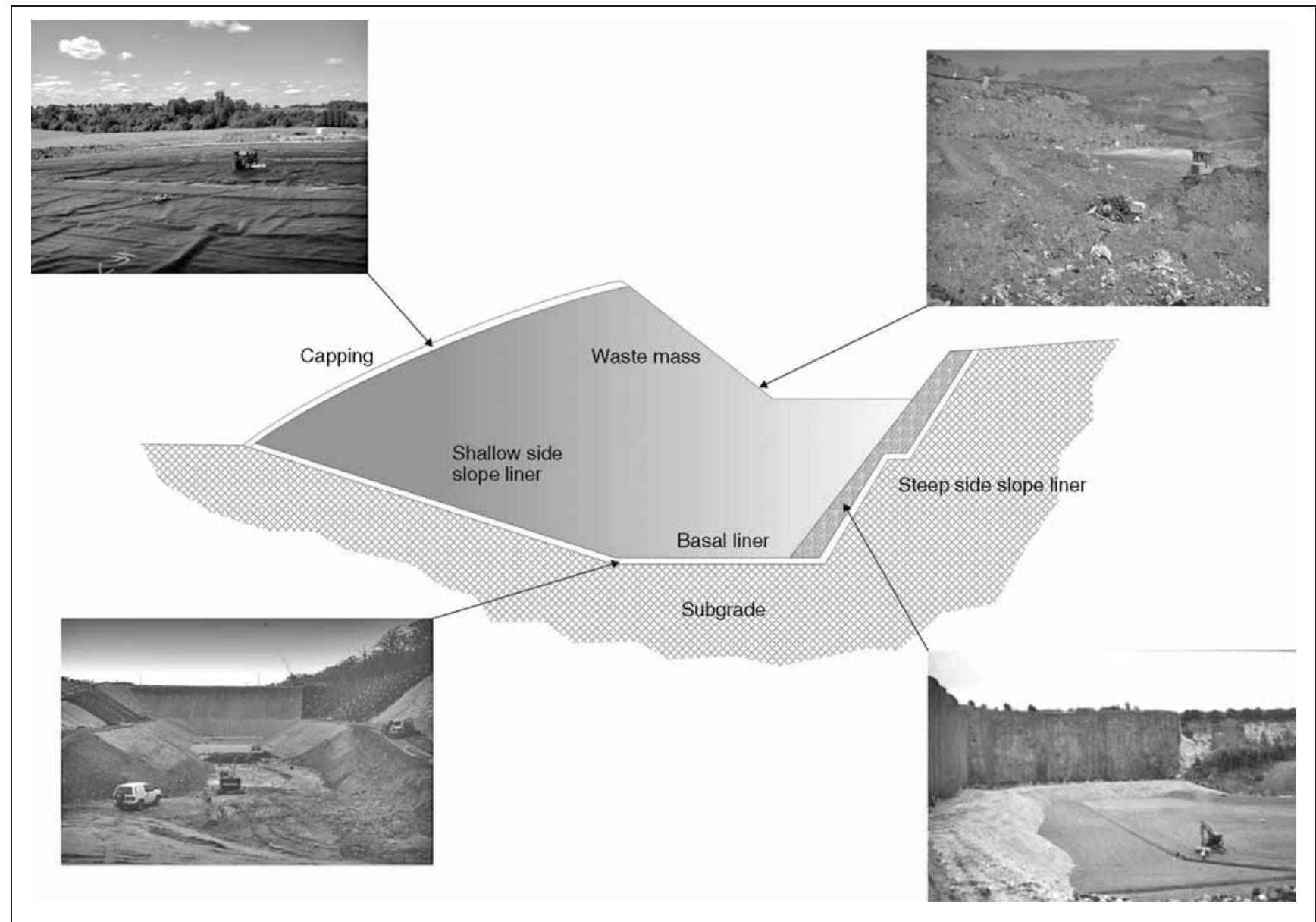

Fig. 2. Landfill lining system design cases

on steep gradients, the absence of horizontal support at this stage means that stability is dependent on the internal strength of the subgrade and the lining system. During the transient construction stage, the subgrade will become confined; following waste placement, the lining system will also become confined. However, the additional weight of the overlying material and downdrag associated with waste settlement means that consideration of stability and integrity post waste placement is still required.

\section{I. Subgrade}

When assessing the subgrade, the potential failure scenarios that should be considered include basal heave, slope instability, potential void formation and subgrade compressibility (see Fig. 4). The considerations will be different depending on whether the base is a natural or engineered subgrade or if it overlies existing waste. To assess cavities in a non-waste subgrade, adequate site investigation is required to gain an understanding of the potential for soil collapse and settlement. For a waste subgrade, the waste stream, method of placement, and compaction and age of the waste will need to be considered in order to assess the likelihood of voids formation and the expected magnitude and distribution of settlements, both total and differential.

The subgrade should be stable, both during and after construction, to prevent movements that may damage the overlying lining system. Stability must be assessed for cut, fill and natural slopes (see Fig. 4). For sloping subgrade, the design issues will include stability, deformations and void potential. For slopes in finegrained soils, time-dependent failure mechanisms should also be considered as short-term stability does not guarantee long-term stability even following waste placement. ${ }^{15}$ Rock mass stability assessments should consider the nature of the rock mass and jointing patterns in order to ensure that the slope will remain stable during and after waste construction. In quarry landfills the stability of rock slopes must be considered as many old quarry slopes are marginally stable following extraction; re-profiling of such slopes may be required for safe working.

\subsection{Basal lining system}

For a basal lining system, potential deformations in the subgrade and lining elements (leading to overstressing of barrier layers and loss of function) must be considered. Basal stability must be ensured (section 3.1) or likely deformations during the life of the facility must be accounted for in design of the lining system.

3.2.1. Influence of subgrade on the lining system. Settlement of the subgrade may occur due to loadings from the overlying waste. The lining system must be designed so as to retain its integrity if subjected to differential settlements (see Fig. 5 (a)). The potential for cavities in the subgrade may require the inclusion of a geogrid to provide support to the lining materials and waste mass over the void. ${ }^{16}$ Geogrids can be used as a means of averaging settlement profiles across the site where significant total and differential settlements are likely to occur. Allowable deformations in a clay liner due to settlement vary depending on soil composition, stress state and plasticity. ${ }^{17}$

3.2.2. Subgrade fluid pressure and basal heave. Pore fluid in the subgrade can generate hydraulic gradients in a mineral barrier, 


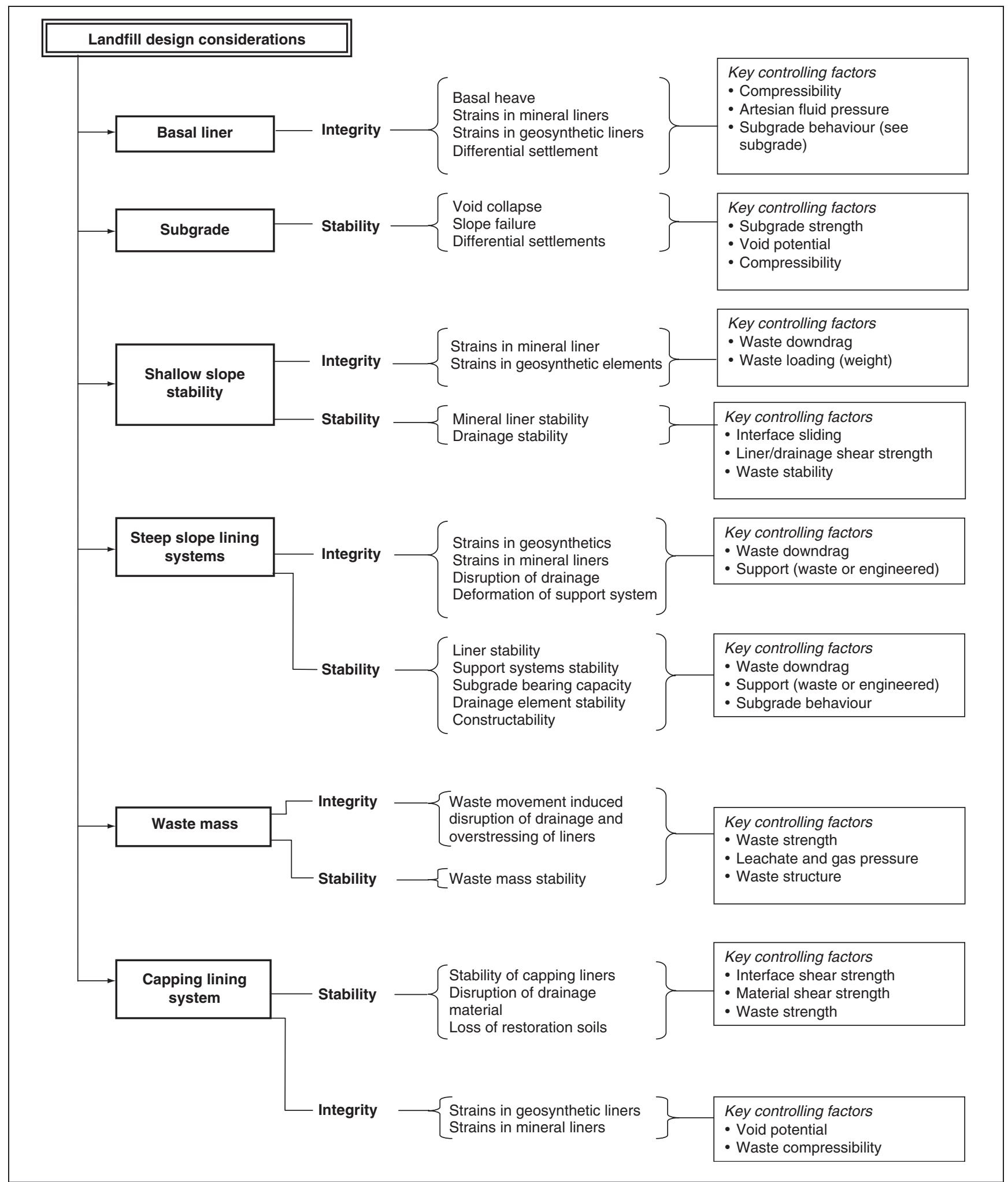

Fig. 3. Landfill lining system design considerations

leading to softening and potential shear failure. A landfill failure resulting from softening of the compacted clay barrier layer due to uncontrolled groundwater in the mudstone subgrade has been reported. ${ }^{2}$ This occurred during periods of heavy rainfall resulting in a high hydraulic gradient of upward flow through the liner together with a build up of surface water. This resulted in saturation of the clay liner and the toe of the side slope and slumping of the clay. Under-drainage was installed and pumping carried out to relieve the pore pressure in the subgrade. In order to ensure barrier integrity is maintained, fluid pressure in the subgrade should be considered for the design life of the landfill site, and under-drainage installed if necessary.

Basal heave can occur if the pore water pressure at a given depth in the subgrade is greater than the total stress from the overlying strata (Fig. 5(b)). The presence of a natural low-permeability layer or the placement of a low-permeability fine-grained barrier layer will prevent release of this fluid pressure into the landfill void; upward movement of the landfill base may thus occur. Basal heave is predominantly an issue prior to waste placement, 


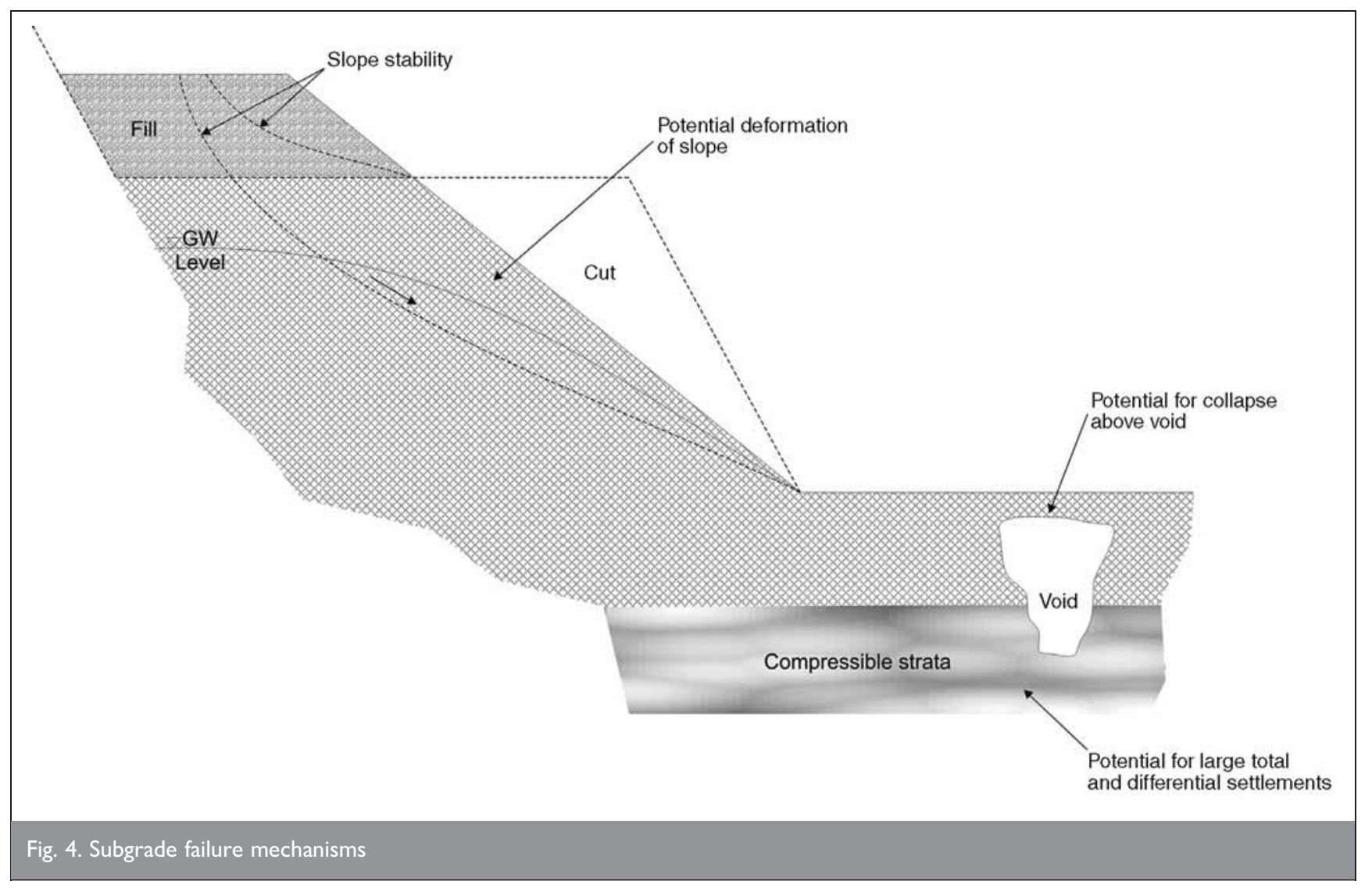

however it may also occur following waste placement if the waste mass exhibits a low unit weight.

\subsection{Side slope lining systems}

The design considerations highlighted in this section are for both shallow- and steep-sided slopes. Stability and integrity of the liner elements, as well as the stability of the subgrade, should be considered both pre (Fig. 6 (a)) and post (Fig. 6(b)) waste placement, as waste placement introduces additional forces onto the lining system. As with a basal lining system, the behaviour of the subgrade can also control the integrity of the side slope lining system. Time-dependent waste degradation and creep can occur, introducing additional forces in liner elements post closure.

\subsubsection{Waste settlement induced strains in lining elements. Waste} downdrag must be considered in both waste-supported and selfsupporting lining systems. The behaviour of such a system can be likened to negative skin friction in a pile foundation. As the waste settles due to both the weight of successive waste lifts and subsequent settlement due to degradation and creep, downwards movement of the waste mass will induce downdrag forces on the lining system. ${ }^{13}$ These forces must be dissipated to prevent overstressing of geosynthetic barrier layers or loss of function of protection layers (Figs 6(b) and 7). Two design philosophies can be adopted in order to preserve the integrity of the underlying lining system. The system can be made sufficiently robust so that it is unaffected by these additional forces; alternatively, the system can be designed to dissipate the stresses through the use of preferential slip planes or sacrificial materials in order to prevent stress transfer into the lining system. Pre-compacted waste or inert fill can be placed adjacent to the waste barrier interface to buffer the lining system from the settling waste mass and also to improve lateral support conditions.
Drainage layers can become distorted or localised failures can occur due to insufficient horizontal support and waste downdrag (Fig. 6(b)). The drainage layer is essential to prevent accumulation of leachate against the lining system and to relieve gas pressures.

3.3.2. Geosynthetic anchorage. As part of an assessment of geosynthetic interface sliding and geosynthetic barrier layer integrity, the anchorage of a geosynthetic system must be considered (see Figs 6(a) and 6(b)). If geosynthetics are used in the lining system, these can be anchored to prevent uncontrolled sliding of the geosynthetics. If one end of a geosynthetic is fixed, stresses transferred into the lining system will result in tensile stresses and associated strains within the geosynthetic.

During construction, temporary anchoring of geosynthetic elements may be considered in order to restrict relative movement. Where waste is constructed in lifts, the waste will be placed prior to the provision of final permanent anchorage. In this case, the effect of the self-weight of the waste and settlement-induced downdrag will already be acting on the material before the permanent anchorage is complete. During the final stages of construction, the geosynthetic may be permanently anchored to resist slippage in the final stages of waste placement, compaction and post placement settlement.

Consideration must be made as to whether geosynthetic anchorage is required. For example, the upper layer of a two-layer slip surface geotextile system may not be anchored at all to allow for movement on the lower interface. However, the lower layer should be anchored as, typically, this layer would be required not to slip. The argument could be made that geosynthetic anchorage should not be required as it only acts to concentrate stresses and only comes into effect if slippage has occurred in the interfaces. 


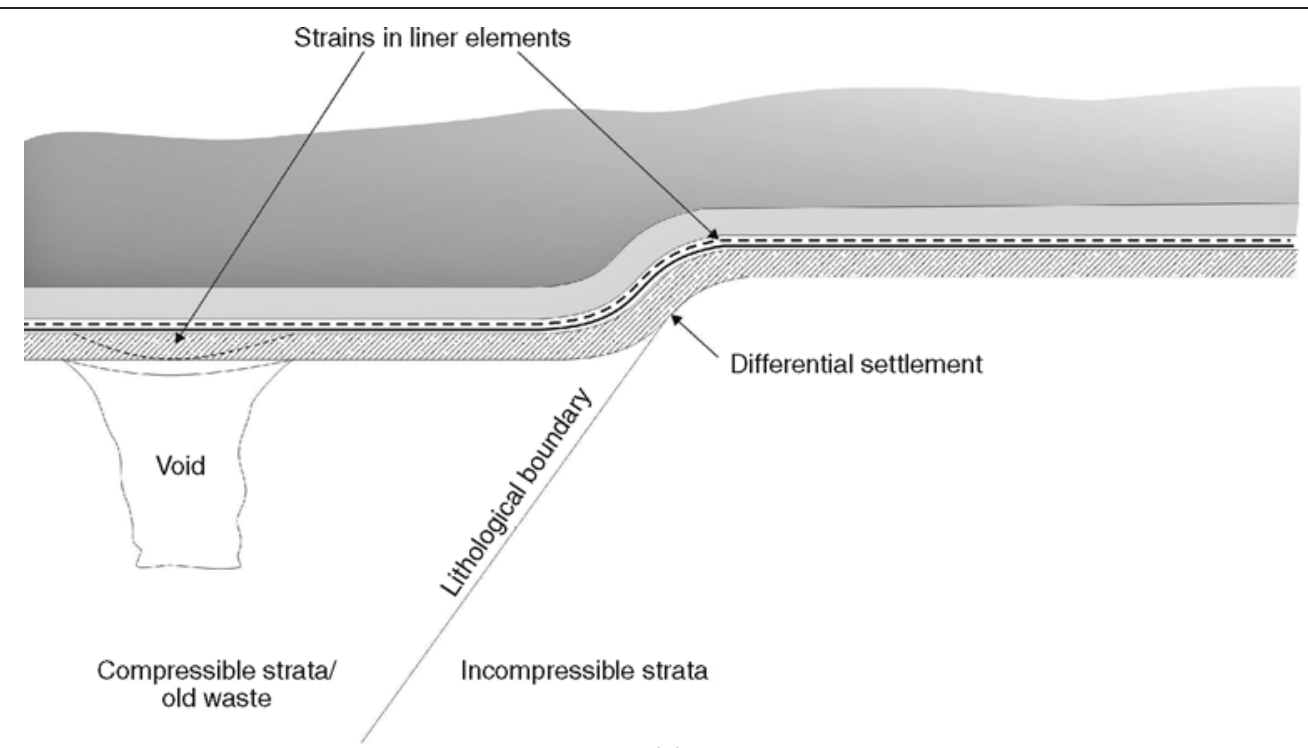

(a)

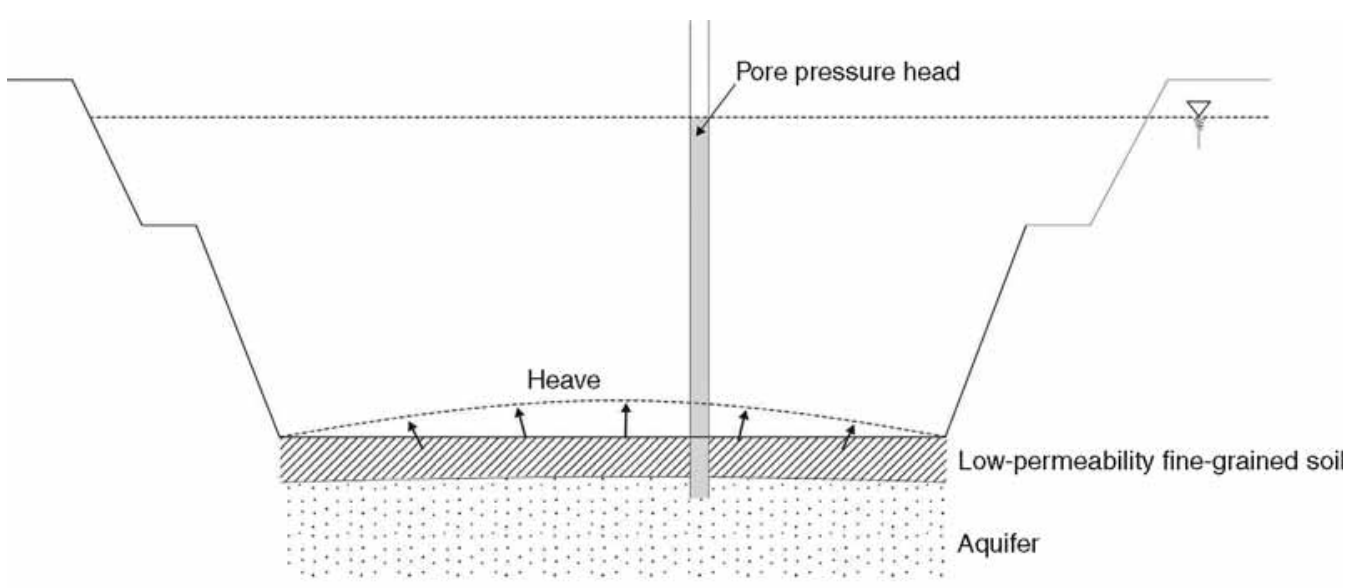

(b)

Fig. 5. Basal lining system failure mechanisms: (a) differential settlement and void collapse; (b) basal heave

Interface engineering should be the primary method of slippage prevention, not anchorage of the geosynthetics.

\subsection{Steep side slope lining systems}

Steep side slope lining systems present additional technical challenges. Figs 3 and 7 demonstrate design considerations for a liner construction that must be satisfied both with and without waste support. With waste support, the lining system is constructed ahead of waste placement but, unlike self-supporting lining systems, it relies on the waste to apply a horizontal force resisting movement of the lining system. Waste is considered to be part of the liner support system. The key design considerations for a steep-sided lining system are $^{18}$

(a) provision of an adequately smooth supporting surface as required

(b) ensuring stability of the whole system

(c) selection of a system that will ensure the required support, integrity and compatibility of the barrier and the protection layers in the context of the settling waste body.

Leachate and landfill gas containment requirements must still be retained in a steep-slope lining system. ${ }^{19}$ In addition, mineral and artificial components of the lining system should be considered from both stability and integrity points of view and it is important to integrate these aspects to produce an effective yet viable design. Possible stability failure mechanisms include shear failure of the lining system and toppling of the lining system; integrity failure can occur as a result of geosynthetic element overstressing and straining of mineral barrier layers (Fig. 7).

3.4.1. Inclusion of a geological barrier. The 1999 EC Landfill Directive $^{4}$ specifies inclusion of a geological barrier along the base and up the side slopes of a landfill, regardless of the angle of the lining side slopes. Clay barriers can be placed on slopes of up to 1(vertical) : 2 (horizontal) for relatively small heights. ${ }^{20}$ Greater slope angles are required for use in steep-wall lining systems and hence a compacted clay barrier layer would need some lateral support to maintain stability. Strains in the lining system can occur due to waste overburden stresses or waste settlement (downdrag). The dominant shear force is dependent on the waste material and side slope angle. Shear stresses in lining elements due to waste weight and downdrag may be estimated by numerical methods, ${ }^{14}$ although there is still a requirement for validation of such techniques.

A reported field trial to investigate the interaction of a steep $\left(80^{\circ}\right)$ side slope compacted clay barrier system supported by a gabion wall and waste found the following. ${ }^{21}$ 


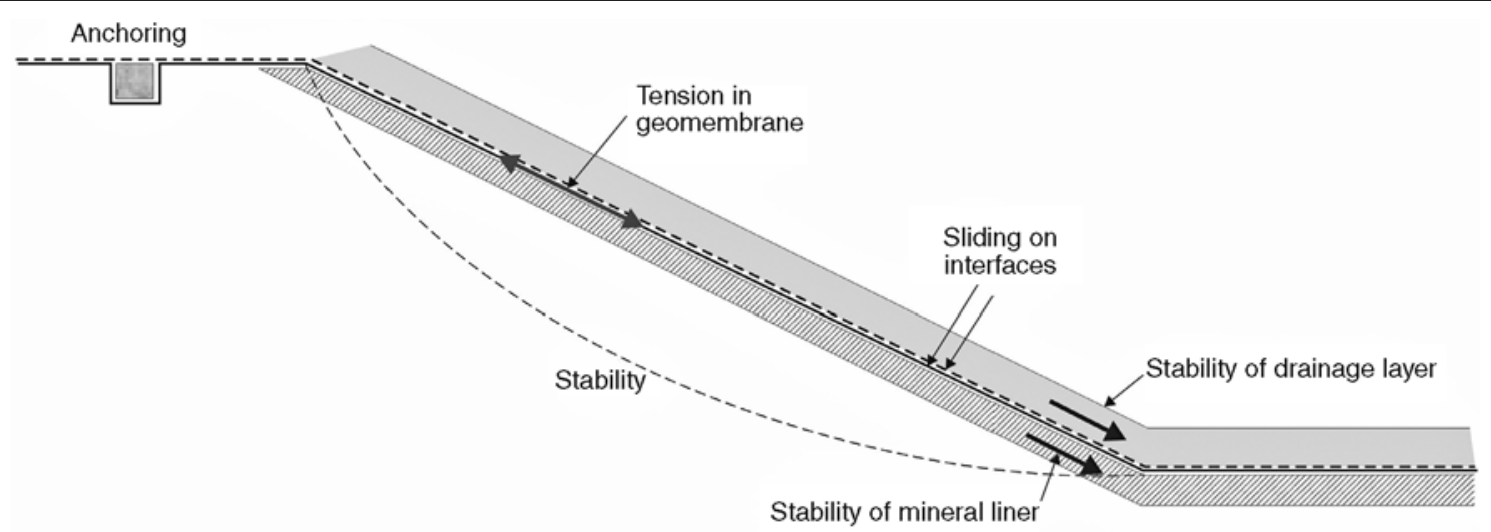

(a)

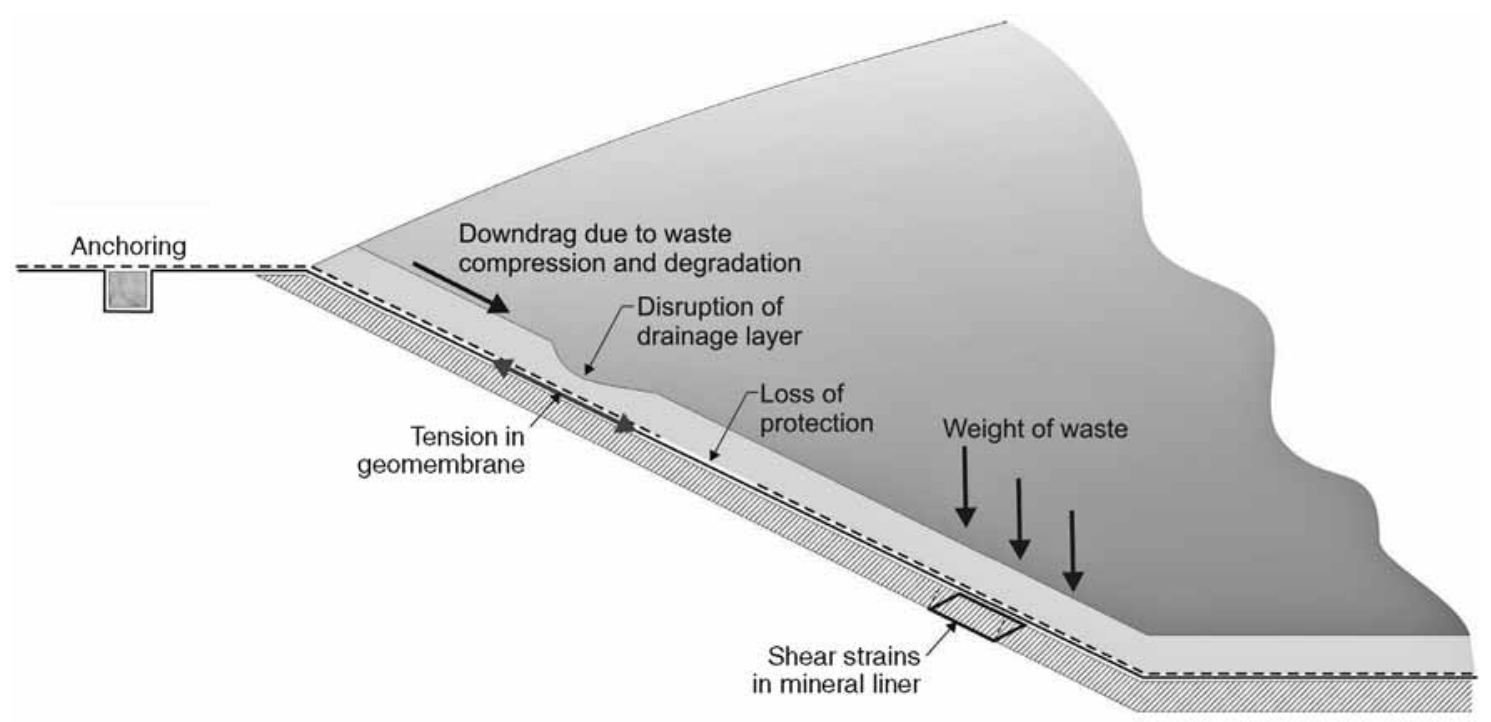

(b)

Fig. 6. Side slope lining system failure mechanisms: (a) unconfined; (b) confined

(a) The barrier experienced significant vertical and horizontal strains, with magnitudes dependent on the stiffness of the waste body.

(b) The method of construction, including the phasing of barrier construction and waste lifts, has an influence on the magnitude and distribution of barrier deformations.

(c) Differential vertical strains were noted in the barrier components.

(d) A number of failure mechanisms were predicted resulting from the magnitude of deformations required for equilibrium between the barrier and waste body. These included shear failure, bulging failure, toppling failure and bearing failure.

Failure of a compacted clay lining system in the UK, where the liner suffered toppling failure and moved away from the quarry wall due to lack of support from the waste, has been reported. ${ }^{22}$ This study showed that the findings listed above ${ }^{21}$ are relevant to UK practice and that the current UK waste stream placed using typical compaction practice is not suitable for supporting a clayonly barrier system on steep slopes.

A geological barrier may be stable in the short term due to its high undrained shear strength. However, in the long term, drained conditions will occur and the barrier will require support. Internal support has been considered for strengthening geological barriers; however, any form of continuous reinforcement may provide a preferential flow path through the materials. The use of discrete fibre reinforcements has also been considered. ${ }^{23}$ However, the inclusion of such reinforcement in stiff clays is reported to be unviable, and strength increases in BESs are only reliable if the moisture content of the material remains sufficiently low not to lubricate the soil-fibre interface. Due to these concerns over internal support approaches, it is preferable for the clay barrier to be externally supported either by the waste itself or by an engineered supporting structure. This could consist of an engineered fill wedge or a reinforced soil structure. Care must be taken if designing a benched quarry as the support for the geological barrier may have to be placed on top of the geological barrier in subsequent lifts. There is potential for increased strains in this scenario (Fig. 7), particularly at the corners of the benches. ${ }^{14}$ Numerical analysis is often necessary in order to assess deformations that may occur in a geological barrier.

\subsubsection{Waste support. A self-supporting lining system can be} constructed to its full height in the absence of waste support. However, two financial factors restrict the use of such systemsconstruction cost and, if the system is wide, loss of void space and hence loss of revenue. When considering a waste-supported lining 


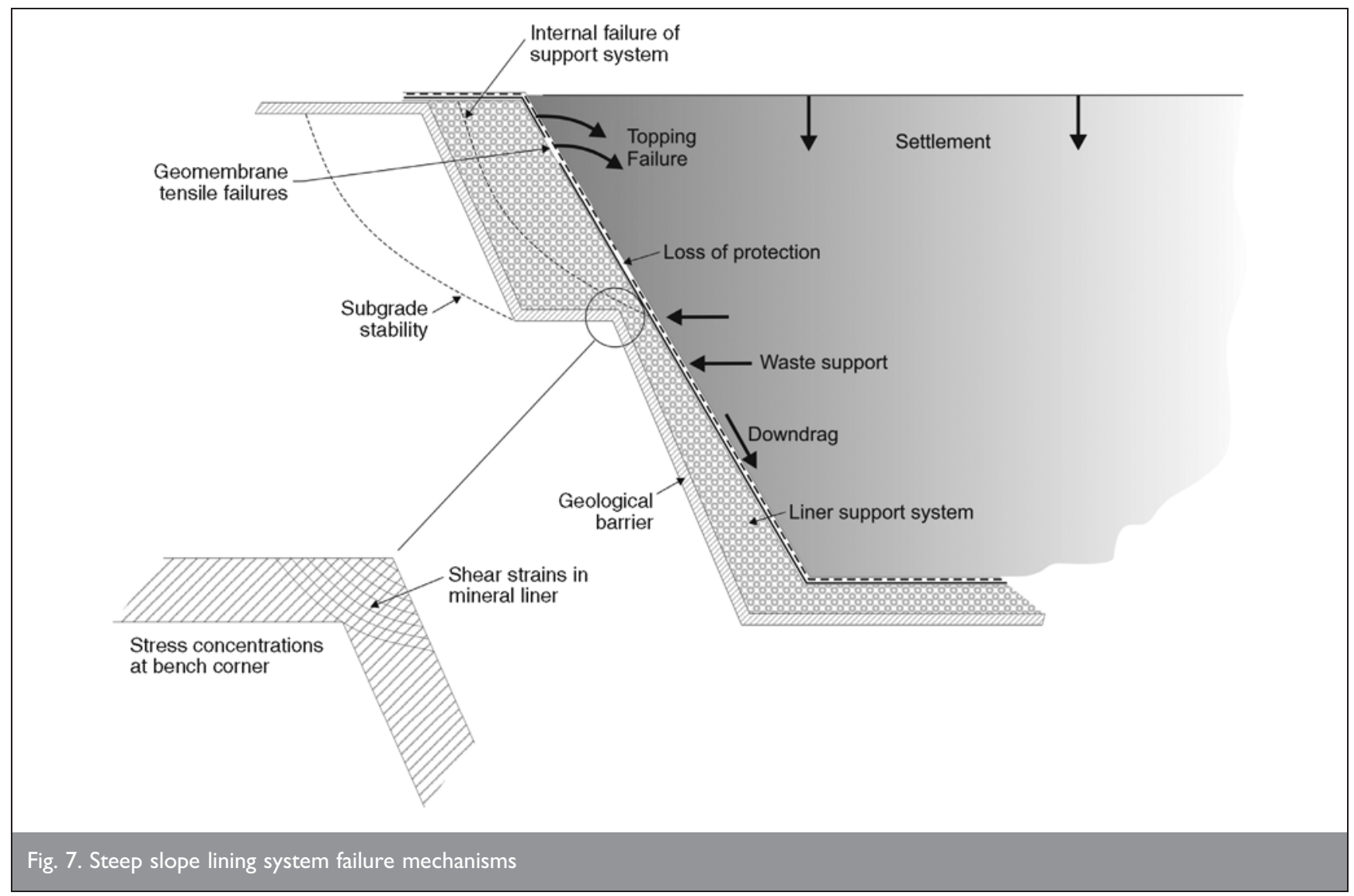

system, it should be noted that two distinct aspects of support will act on the lining system. Firstly, the waste will apply some lateral support, which can be calculated using a coefficient of horizontal earth pressure $K_{0}{ }^{24}$ Secondly, should the lining system begin to deform, the waste stiffness will control the magnitude of deformation and may prevent stability failure. It should be appreciated that movements to mobilise the waste resistance can be large due to its low stiffness ${ }^{22}$ and hence integrity failures may still occur. If waste support is insufficient, shear or toppling failures of the lining system may occur (Fig. 7).

In addition to waste composition, lateral support is also a function of compaction practice adjacent to the lining system. There is a tendency, on site, to avoid compaction directly adjacent to the lining system due to concerns that this may result in mechanical damage to the liner. However, this practice may have the adverse effect and leave the lining system more vulnerable to deformation and hence loss of integrity. In order to fully understand support offered from the waste, its mechanical behaviour must be understood. Reviews of the current understanding of landfill engineering and waste mechanics ${ }^{25,26}$ highlight areas that require further research. Important characteristics, e.g. coefficient of earth pressure at rest and stiffness, are still poorly understood with only a limited number of studies available in the literature.

\subsection{Waste mass stability}

Two types of waste slope failures should be considered-those involving waste mass alone and those involving the lining system and/or subgrade (Fig. 8). Due to the highly heterogeneous nature of the waste mass it is unlikely that the actual strength characteristics will, or in fact could, be known. Therefore, conservative parameters should be selected that are appropriate to the waste stream, waste placement techniques and compaction practice for a particular site. Failures in the waste mass can occur due to exposed waste slope angles exceeding the shear strength of the waste body. Instability can also be induced by relic weak layers such as temporary soil cover layers, weak waste layers or leachate pressures within the waste body. Failure of a temporary waste slope due, partially, to sliding of the waste mass on an old cover soil layer has been reported. ${ }^{2}$ As the cover soil did not contain reinforcing elements (i.e. plastic) that were present in the waste body, it formed a weak plane along which preferential shearing occurred.

Leachate can be collected in the base, perched within the waste or can be present throughout the waste body (Fig. 8) especially if recirculation is active. An $800000 \mathrm{~m}^{3}$ slide of waste occurred mainly due to injection of leachate as part of the recirculation strategy in conjunction with inadequate leachate- and gascollection systems. ${ }^{27}$ Gas and leachate pressures in the landfill may result in failure. ${ }^{28}$

Designers must consider failures where the critical surface incorporates the lining system. Sliding can occur due to shearing within mineral layers, on geosynthetic interfaces, or internal failure of geosynthetic composites. Increased pore fluid pressure in liner components and along interfaces increases the likelihood of such failures; the leachate and groundwater conditions in the subgrade should thus be taken into account and controlled where required.

Translational failures of the whole waste mass along interfaces and composite failures involving both shearing of waste and interfaces must be considered. Movement along interfaces can mobilise post peak strengths and hence increase the possibility of 


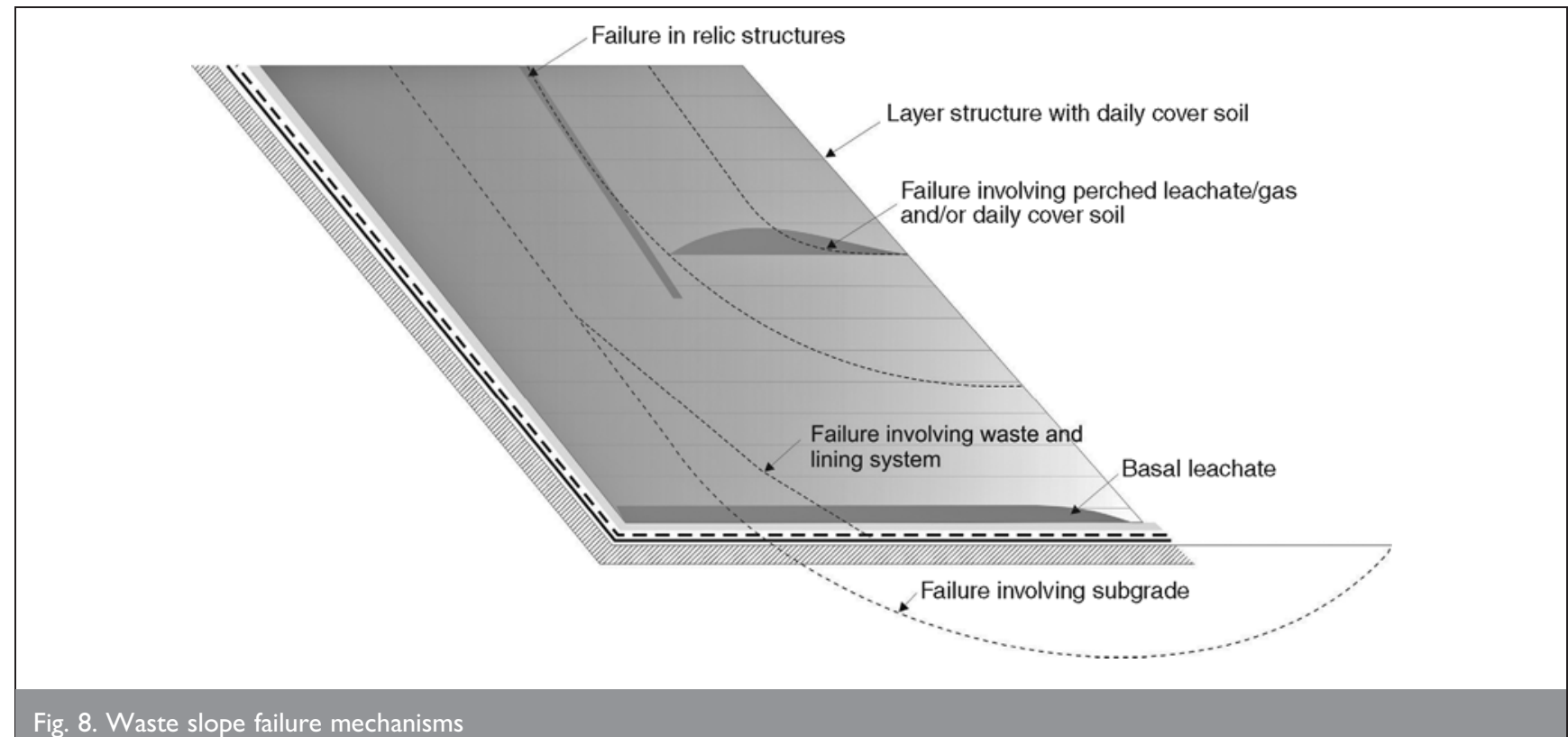

Fig. 8. Waste slope failure mechanisms

failure. Post peak strength can be mobilised during construction and by subsequent loading as the waste is placed and settles. ${ }^{13} \mathrm{~A}$ landfill failure occurred due to sliding along weak planes provided by interfaces. ${ }^{29}$ Mobilisation of post peak interface shear strengths occurred at small displacements which, it was suggested, ${ }^{29}$ were likely to have been exceeded during the construction and filling phases. A translational slide was reported ${ }^{2}$ in which a sacrificial layer of soft clay was left in place to limit damage and desiccation and was subsequently covered by geomembrane. This layer provided a low shear strength layer along which preferential shearing occurred.

Subgrade-related failures may still occur following waste placement. These can be driven by the increased loading from the waste mass, particularly if the underlying subgrade experiences undrained loading. Groundwater rebound following void infill or cessation of pumping can also result in subgrade instability. A landfill failure involving low-strength native soil underlying waste has occurred. ${ }^{30}$ Adequate site investigation must therefore be carried out to characterise the subgrade and likely areas of low strength leading to potential instability. While many infill (i.e. quarry type) landfills do not have steep waste slope profiles as part of the final design, it is common to form temporary waste slopes during cell construction and staged filling, with such slopes typically have gradients up to 1 (vertical) :2(horizontal). There have been a number of failures of temporary waste slopes in the UK in recent years and it is thus important for designers to check the stability of all waste slopes that are formed during the filling process.

\subsection{Capping lining systems}

The landfill cap is exposed to the environment and designers must consider the potential for degradation or damage to this lining system. Due to heterogeneity of the underlying waste material, differential settlements are likely under the capping system. All capping elements should be assessed in terms of overall stability and integrity (Fig. 9).

The stability of the capping system must take into account potential failures between and within liner elements, and

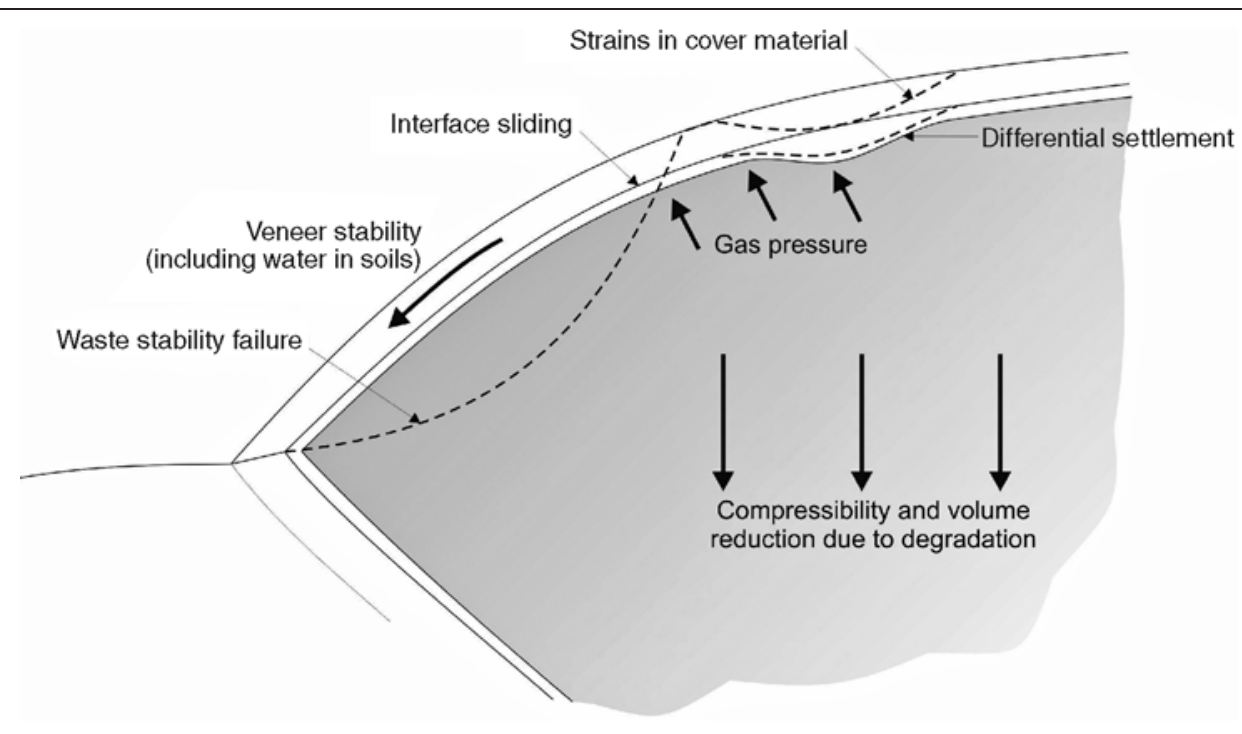


involving the underlying waste, restoration soils and drainage materials. Material and interface shear strengths are required for analysis as well as an understanding of the likely pore fluid conditions in the capping system. Even with inclusion of a drainage layer the cap may be susceptible to saturation in extreme rainfall conditions. Gas pressure acting on the underside of the barrier may reduce stability beneath the barrier layers and, therefore, such permeable layers could be included below the barrier layer to allow migration of landfill gas. $^{31}$

Figure 3 identifies the integrity mechanisms to be considered. These include slope deformations and differential deformation of the cap resulting from cavities in the underlying waste and waste settlement. Due to the likelihood of differential settlements, materials may be selected that can accommodate greater deformations without loss of function such as LLDPE geomembranes or high-plasticity fine-grained soils.

\section{SUMMARY}

A design framework has been put forward for assessing the stability and integrity of landfill lining systems. The framework covers the general design cases for subgrade, basal lining system, shallow side slope lining systems, steep side slope lining systems, waste slopes and capping lining systems. The guidance is not intended to be prescriptive and direct engineers how to design each aspect of the lining system, but to highlight relevant issues that should be considered. It should be noted that the factors presented here do not form an exhaustive list and all site-specific issues should be considered.

Although design is very important, a good design alone will not ensure adequate performance of a landfill lining system. Construction quality assurance (CQA) should be carried out during construction to ensure that the lining system meets the design specification. Material properties should all be verified as deficiencies can invalidate the functionality of the entire design.

Design using generic properties derived from literature values, previous experience or index testing can lead to potentially high-risk designs, especially where the properties exhibit large inherent variability. Site-specific performance testing on subgrade and lining system components reduces this risk, allowing greater confidence in designs and potential cost savings.

In order to fully understand and assess the structural performance of landfill lining systems, they should be instrumented in order to monitor structural behaviour during construction, waste placement and post completion. This will improve confidence in long-term behaviour, lead to optimised designs and reduce risk. Integrity and deformation analysis using numerical analysis is becoming more common. However, validation of such numerical models is insufficient and field instrumentation is required to address this.

\section{REFERENCES}

1. Jones D. R. V., Dixon N. and Storey S. M. Lessons learnt from UK landfill failures. Proceedings of the 9th International Waste Management and Landfill Symposium, Cagliari, Sardinia, 2003, 511.
2. Jones D. R. V. and Dixon N. Stability of Landfill Lining Systems: Literature Review. Environment Agency Research and Development Project P1-385, 2003, Report TR1.

3. DiXon N. and Jones D. R. V. Stability of Landfill Lining Systems: Guidance. Environment Agency Research and Development Project P1-385, 2003, Report TR2.

4. Council of the European Union. Directive 1999/31/EC on the landfilling of waste. Official Journal of the European Union, 1999, L182, 1-19.

5. The Landfill (England and Wales) Regulations 2002. HMSO Statutory Instrument 2002, No. 1559.

6. Construction (Design and Management) Regulations 2007. HMSO Statutory Instrument 2007, No. 320.

7. Needham A. D., Smith J. W. N. and Gallagher E. M. G. The service life of polyethylene geomembrane barriers. Engineering Geology, 2006, 85, No. 1-2, 82-90.

8. Dixon N., Jones D. R. V. and Fowmes G. J. Interface shear strength variability and its use in reliability-based landfill stability analysis. Geosynthetics International, 2006, 13, No. 1, 1-14.

9. ZORnBERG J. G., McCARTney J. S. and Swan R. H. Analysis of a large database of GCL internal shear strength results. Journal of Geotechnical and Geoenvironmental Engineering, 2005, 131, No. 3, 367-380

10. Eurocode 7. Geotechnical Design, Part 2: Design Assisted by Laboratory testing. 1997, ENV 1997-2:1999.

11. Gilbert R. B., NAJJar S. S. and Shields M. K. Importance of residual strengths in factors of safety and reliability. Proceedings of Geo-Frontiers 2005, the 18th GRI Conference on Geosynthetics Research and Development in Progress, Reston, Virginia, 2005, CD-ROM.

12. DiXon N. and Jones D. R. V. Design interface shear strengths: peak or residual? Proceedings of Geosynthetics, Protecting the Environment, the 1st IGS (UK) 1 Day Symposium, Nottingham, 2003, 52-70.

13. Jones D. R. V. and Dixon N. Landfill lining stability and integrity: the role of waste settlement. Geotextiles and Geomembranes, 2005, 23, No. 1, 27-53.

14. FOWMES G. J., JONES D. R. V. and DiXON N. Analysis of a landfill directive compliant steepwall lining system. Proceedings of the 10th International Waste Management and Landfill Symposium, Sardinia, 2005, 369pp.

15. Chandler R. J. and Skempton A. W. Design of permanent cutting slopes in stiff fissured clays. Geotechnique, 1974, 24, No. 4, 457-466.

16. Giroud J. P., BOnAPArte R., Beech J. F. and Gross R. A. Load-carrying capacity of a soil layer supported by a geosynthetic. Proceedings of International Geotechnical Synposium on Theory and Practice of Earth Reinforcement (Yamanouchi T., Miura N. and Ochiai H. (eds)). Balkema, Rotterdam, 1988, pp. 185-190.

17. Katzenbach R., Amann P. and Edelmann L. Investigation of limiting values of deformability for mineral landfill liners by simulation of deformations in 1:1 scale tests. In Advanced Landfill Liner Systems (AUGust H., HolzoHNER U. and Meggyes T. (eds)). Thomas Telford, London, 1995, pp. 123-131.

18. Gallagher E. M. G., Needham A. D. and Smith D. M. Use of geosynthetics in landfill steepwall lining systems. Proceedings of the East Midlands Geotechnical Group Symposium (Dixon N., Murray E. J. and Jones D. R. V. (eds)). Thomas Telford, London, 2003, pp. 71-91. 
19. Cowland J. W., Bouazza A. and Sadlier M. A. Leachate containment in quarry landfills. Proceedings of the 5 th International Conference on Environmental Geotechnics, Cardiff, 2006, 1, 701-708.

20. Hertweck M. and Amann P. Slope stability of clay liners at waste deposit rock walls. Proceedings of the 14th International Conference on Soil Mechanics and Foundation Engineering, Hamburg, 1997, 1, 687-690.

21. Edelmann L., Hertweck M. and Amann P. Mechanical behaviour of landfill barrier systems. Proceedings of the Institution of Civil Engineers, Geotechnical Engineering, 1999, 137, No. 4, 215-224.

22. DIXON N., NG'AMBI S. and JoNES D. R. V. Structural performance of a steep slope landfill lining system. Proceedings of the Institution of Civil Engineers, Geotechnical Engineering, 2004, 157, No. 3, 115-125.

23. FOWMES G. J., DIXON N. and JoNES D. R. V. Use of randomly reinforced soils in barrier systems. Proceedings of the 5th International Congress on Environmental Geotechnics, Cardiff, 2006, 709-716.

24. DiXon N. and Jones D. R. V. Engineering properties of municipal solid waste. Geotextiles and Geomembranes, 2005, 23, No. 3, 205-233.

25. KAVAZANJIAN E. Waste mechanics: recent findings and unanswered questions. Proceedings of Geoshanghai, Keynote Paper, June 2006.
26. Jones D. R. V. and DiXon N. Landfill engineering: a technical challenge or old hat? Proceedings of Waste 2006 (Vegh B. and Royle J. (eds)). Waste Conf. Ltd, Coventry, 497-506.

27. Caicedo B., Giraldo E. and Yamin L. The landslide of Dona Juana landfill in Bogota: A case study. In Environmental Geotechnics, 4th ICEG (DE Mello L. G. and Almeida M. A. A. (eds)). Balkema, Lisse, 2002, pp. 171-175.

28. Kavazanjian E. and Merry S. M. The 10 July 2000 Payatas landfill failure. Proceedings of the 10th International Waste Management and Landfill Symposium, Sardinia, 2005, p. 587.

29. Mitchell J. K., Seed R. B. and Seed H. B. Kettleman Hills waste landfill slope failure. I: Liner system properties. ASCE Journal of Geotechnical Engineering, 1990, 116, No. 4, 647-668.

30. Eid H. T., Stark T. D., Evans W. D. and Sherry P. E. Municipal soil waste slope failure. I: Waste and foundation soil properties. Journal of Geotechnical and Geoenvironmental Engineering, 2000, 126, No. 5, 397-407.

31. THIEL R. Design and testing of a NWNP geotextile gas pressure relief layer below a geomembrane cover to improve slope stability. Proceedings of 7 th International Landfill Symposium, Sardinia, 1999, III, 343-350.

\section{What do you think?}

To comment on this paper, please email up to 500 words to the editor at journals@ice.org.uk

Proceedings journals rely entirely on contributions sent in by civil engineers and related professionals, academics and students. Papers should be $2000-5000$ words long, with adequate illustrations and references. Please visit www.thomastelford.com/journals for author guidelines and further details. 